\title{
Acetate and Acetamide Mutants of Pseudomonas aeruginosa 8602
}

\author{
By A. J. SKINNER AND PATRICIA H. CLARKE \\ Department of Biochemistry, University College, London
}

(Accepted for publication 8 July 1967)

\begin{abstract}
SUMMAR Y
Mutants of Pseudomonas aeruginosa 8602 were isolated which were unable to grow with acetamide as sole carbon source. They were divided into five classes on the basis of growth studies and enzyme assays. The mutants able to grow on acetate but not acetamide $\left(\mathrm{Am}^{-}\right)$lacked an inducible amidase. Mutants unable to utilize either acetamide or acetate ( $\mathrm{At}^{-}$) lacked one of the glyoxylate cycle enzymes (isocitrate lyase or malate synthase) or were deficient in citrate synthase or acetic thiokinase. Isocitrate lyase-negative mutants grew on propionate which is therefore not metabolized by the glyoxylate cycle. The amidase marker was not co-transduced with the isocitrate lyase, acetic thiokinase or citrate synthase markers.
\end{abstract}

\section{INTRODUCTION}

Pseudomonas aeruginosa 8602 produces an inducible amidase (aliphatic acylamide amidohydrolase EC 3.5.I.4) in media containing acetamide and this enzyme accounts for the hydrolysis of acetamide to acetate and ammonia (Kelly \& Clarke, I962). Microbial growth on acetate is thought to involve the reactions of the glyoxylate cycle enzymes (Kornberg \& Krebs, 1957) and the specific activities of isocitrate lyase and malate synthase are sufficiently high in acetate-grown pseudomonads to account for the biosynthesis of succinate and other compounds required for growth (Kornberg, Gotto \& Lund, I958; Kornberg \& Lund, 1959). We have isolated several mutants of $P$. aeruginosa 8602 which are unable to grow on acetamide and acetate. These mutants have been examined by growth and enzyme studies to investigate the metabolism of acetate and related compounds. We have previously shown co-transduction of the amidase structural and regulator genes (Brammar, Clarke \& Skinner, 1967). Similar transduction analysis was used to examine the genetic linkage of the acetate mutants. A brief report of part of this work has appeared previously (Skinner \& Clarke, 1965).

\section{METHODS}

Organism. The parent strain was Pseudomonas aeruginosa 8602 . Amidase-negative mutants are referred to as Am I, etc.; mutants unable to utilize acetate are referred to as At I, etc. Cultures were maintained as previously described (Brammar et al. 1967).

Media. Liquid media were based on the minimal salt medium described by Brammar \& Clarke (1964). Succinate, acetate, pyruvate and propionate (as sodium salts) were added to give a final concentration of $\mathrm{I} \%(\mathrm{w} / \mathrm{v})$. Acetamide was sterilized by Seitz 
filtration and added aseptically to sterile minimal salt medium to a final concentration of $I \%(w / v)$. Solid media contained $I \cdot 2 \%(w / v)$ Oxoid no. 3 or Difco Noble agar. Succinate and acetate agar plates were prepared by adding the appropriate carbon source to minimal agar to a final concentration of $0.5 \%(w / v)$. Acetamide agar plates were prepared by adding sterile acetamide to minimal agar to a final concentration of $0.5 \%(w / v)$.

Growth conditions. Cultures were grown at $37^{\circ}$ on a mechanical shaker in conical flasks of capacity ro times that of the medium volume. Stationary phase cultures for enzyme assays were obtained after overnight growth ( $16 \mathrm{hr}$ ) from an inoculum of $0 . \mathrm{I}$ $\mathrm{ml} . / 20 \mathrm{ml}$. medium. Bacteria were harvested at $0^{\circ}$ in an MSE Angle 17 refrigerated centrifuge at $\mathrm{I} 2,000 \mathrm{~g}$ for $\mathrm{IO} \mathrm{min}$.

Preparation of cell-free extracts. Bacteria were resuspended in cold $0 . \mathrm{I}$ M-phosphate buffer ( $\mathrm{pH} 7 \cdot 2)$ and disrupted with an MSE $25 \mathrm{~W}$ ultrasonic oscillator. Samples ( $2.5 \mathrm{ml}$.) were subjected to an output of $\mathrm{I} \cdot 3 \mathrm{~A}$ for $2 \mathrm{~min}$. in a glass vessel designed for use with the $\frac{1}{4}$ in. probe. Bacterial debris was removed by centrifugation at $25,000 \mathrm{~g}$ for $15 \mathrm{~min}$.

Estimation of protein. The method of Lowry, Rosebrough, Farr \& Randall (I95I) was used to estimate protein, with bovine plasma albumin as a standard.

Enzyme assays. Amidase was measured by the hydroxamate method for transferase activity (Brammar \& Clarke, 1964). For acetic thiokinase (EC 6.2.r.I.) the method of Jones \& Lipmann (1955) was used to detect the formation of acetyl-coenzyme A from acetate in the presence of $\mathrm{ATP}$, coenzyme $\mathrm{A}$, glutathione and $\mathrm{Mg}^{2+}$. Isocitrate lyase (EC 4.I.3.I.), malate synthase (EC 4.I.3.2) and citrate synthase (EC 4.I.3.7) were assayed according to the method of Dixon \& Kornberg (1959) at room temperature by using a Carey Model I 4 or a Unicam SP 800 recording spectrophotometer.

Mutagenic treatment. Ethylmethane sulphonate (EMS) and $N$-methyl- $N$ '-nitro- $N$ nitrosoguanidine (NMG) were used as described by Brammar et al. (1967).

Replica plating. Replica plating was done according to Lederberg \& Lederberg (1952).

Selection of mutants. (a) Replica plating. Mutagen-treated cultures were plated on succinate agar and the colonies replicated to acetamide plates. Colonies which were present on succinate plates but absent from acetamide plates were picked off, resuspended in dilution buffer and streaked on succinate, acetate and acetamide plates. This differentiated mutants unable to utilize acetamide from those unable to grow on either acetate or acetamide. This method provided 6 strains unable to grow on acetate (At ${ }^{-}$). (b) Limiting enrichment (Davis, 1949). Bacteria treated with a mutagen were spread on agar plates containing either $0.05 \%(\mathrm{w} / \mathrm{v})$ acetamide or $0.05 \%(\mathrm{w} / \mathrm{v})$ acetamide $+0.001 \%(\mathrm{w} / \mathrm{v})$ sodium succinate as carbon sources (Brammar et al. 1967$)$. After $48 \mathrm{hr}$ incubation, plates were examined for small or opaque colonies; these were picked off, resuspended in dilution buffer and streaked on succinate, acetate and acetamide plates.

Transduction analysis. The pseudomonad phage F II6 (Holloway, Egan \& Monk, I960) was used as described previously (Brammar et al. 1967).

Reagents. Acetamide was obtained from Hopkin and Williams Ltd. and recrystallized twice from ethanol for use in the amidase assay. $N$-acetylacetamide was synthesized from acetamide and acetic anhydride and twice recrystallized from methylethylketone. Glutathione and coenzyme A were obtained from C. F. Boehringer und 
Soehne G.m.b.H. Isocitrate was prepared from DL-isocitric lactone obtained from L. Light and Co. Ltd. Acetyl-coenzyme A was prepared according to Stadtman (I957). Adenosine-5'-triphosphate. $3 \mathrm{H}_{2} \mathrm{O}$ (ATP) was purchased as the disodium salt from the Sigma Chemical Company. Bovine plasma albumin was obtained from Armour Laboratories. Ethylmethane sulphonate was obtained from Kodak Ltd. $N$-methyl- $N^{\prime}$ nitro- $N$-nitrosoguanidine was obtained from the Aldrich Chemical Co.

\section{RESULTS}

Mutants unable to grow on acetamide

The mutant isolation procedures provided 32 strains of Pseudomonas aeruginosa unable to grow on acetamide as sole source of carbon and nitrogen; 22 of these strains were also unable to grow on acetate. The 32 strains were grown overnight in succinate

Table I. Growth of Pseudomonas aeruginosa 8602 wild-type and mutant strains

\begin{tabular}{|c|c|c|c|c|}
\hline \multirow[b]{2}{*}{ Strain } & \multicolumn{3}{|c|}{ Carbon source for growth } & \multirow[b]{2}{*}{ Amidase* } \\
\hline & Acetamide & Acetate & Succinate & \\
\hline Wild-type & + & + & + & Present \\
\hline Am I-Am io & - & + & + & Absent \\
\hline At I-At 22 & - & - & + & Present \\
\hline
\end{tabular}

+ , Growth after $24-\mathrm{hr}$ incubation at $37^{\circ} ;-$, no growth after $24 \mathrm{hr}$ incubation at $37^{\circ}$.

* Cultures were grown overnight in $\mathrm{I} \%$ succinate medium with $1 \mathrm{I}^{-2} \mathrm{M}-N$-acetylacetamide as inducer for amidase and assayed according to Brammar \& Clarke (1964).

medium with $\mathrm{N}$-acetylacetamide as a non-substrate inducer for amidase. The Io strains which grew on acetate but not on acetamide all lacked amidase (Table I); the specific activity was less than $\mathrm{I} \%$ of that of the fully induced wild-type strain. They were designated Am I to Am Io. The strains unable to utilize either acetamide or acetate had specific amidase activities which were not significantly different from those of the fully induced wild-type strain. These were classified as acetate-negative mutants and designated At $\mathrm{I}$ to At 22.

\section{Growth of acetate-negative mutants}

Growth of pseudomonads on acetate as sole carbon source is thought to require the tricarboxylic acid and glyoxylate cycles (Kornberg \& Krebs, 1957). As all the acetate-negative mutants were able to grow on succinate it seemed unlikely that they would have major defects in the tricarboxylic acid cycle enzymes. The mutants might be expected to be defective in either of the two specific enzymes of the glyoxylate cycle, isocitrate lyase or malate synthase, or in another enzyme required for acetate metabolism such as acetic thiokinase (Fig. I).

The mutants were tested for growth in minimal medium containing acetate + glyoxylate. Unlike some other pseudomonads, Pseudomonas aeruginosa 8602 does not grow with glyoxylate as sole carbon source. Some mutants unable to grow on acetate might be expected to do so in the presence of added glyoxylate which could be condensed with acetyl-CoA to form malate. However, mutants lacking malate synthase would be unable to use glyoxylate in this way and would not grow on acetate + glyoxylate. The 
addition of glyoxylate to an acetate medium would also have no effect on the growth of strains lacking acetate activating enzymes. $P$. aeruginosa 8602 grows on both propionate and propionamide and the acetate-negative mutants were tested to see whether they had also lost the ability to grow on propionate.

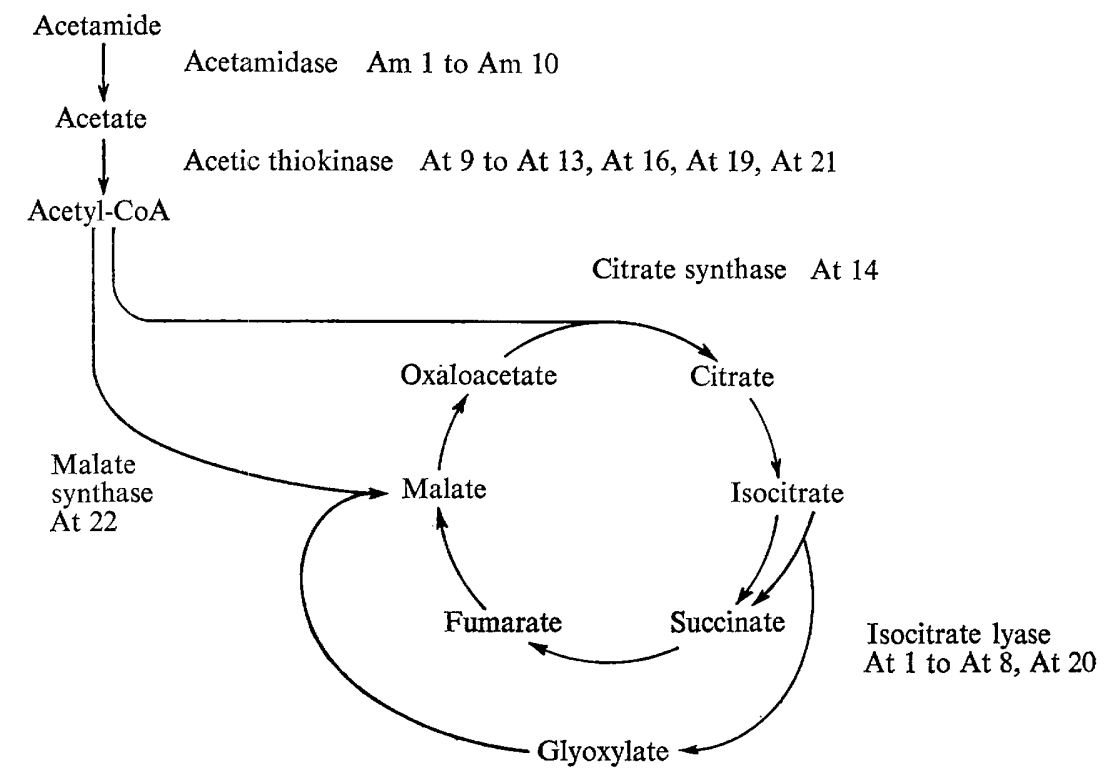

Fig. I. Pseudomonas aeruginosa 8602; pathways of acetamide and acetate metabolism. Am I-Am 10, amidase-negative mutants; At I-At 22, mutants defective in enzymes required for acetate utilization.

Table 2. Growth of Pseudomonas aeruginosa 8602 wild-type and acetate-negative mutants

Carbon source for growth

Strain

Wild-type

At $r$, At 2, At 3 , At 4 , At 5 ,

At 6 , At 7 , At 8 , At 15 , At 20

At 14

At 9, At 16 , At 2 I

At 10, At I I, At 12, At 13,

At 19, At 22

$\overbrace{\text { Acetate }}^{\begin{array}{c}\text { Acetate }+ \\ \text { glyoxylate }\end{array} \text { Propionate }} \begin{gathered}\begin{array}{c}\text { Possible enzyme } \\ \text { defects }\end{array} \\ ++x^{2}\end{gathered}$

$\left.\begin{array}{ccc}++ & ++ & + \\ (-) & ++ & + \\ - & ++ & - \\ (-) & (-) & + \\ (-) & (-) & (-)\end{array}\right\}$

None

Isocitrate lyase

Citrate synthase, malate synthase, acetic thiokinase or other enzymes

++ , Growth (about $10^{\circ}$ bacteria $/ \mathrm{ml}$.) after $\mathrm{I} 6-24 \mathrm{hr}$ incubation at $37^{\circ} ;(-)$, no visible growth after $24 \mathrm{hr}$ incubation at $37^{\circ}$ (some cultures grew after a further $\mathrm{I} 2 \mathrm{hr}$ incubation); +, growth (about $10^{8}$ bacteria $/ \mathrm{ml}$.) after $24-36 \mathrm{hr}$ incubation at $37^{\circ} ;-$, no visible growth after $36 \mathrm{hr}$ incubation at $37^{\circ}$.

Growth of cultures in acetate, acetate + glyoxylate or propionate media was examined visually at intervals during $36 \mathrm{hr}$. Table 2 shows that I I mutants grew on acetate + glyoxylate and 10 of these also grew on propionate. These ro were provisionally classified as isocitrate lyase-defective mutants. As they grew well on acetate + glyoxylate it seemed unlikely that the inability of the wild type to grow on glyoxylate alone was due to impermeability to this compound. Nine mutants were unable 
to grow on acetate + glyoxylate and 6 of these were also unable to grow on propionate. The enzyme patterns of these 20 acetate-negative mutants were investigated. Two other mutants, At 17 and At 18 , have not been examined in detail.

\section{Isocitrate lyase}

The wild-type strain was grown on acetate, propionate and succinate and cell-free extracts were assayed for isocitrate lyase activity (Table 3). It is known that different growth substrates influence the specific activity of this enzyme in Pseudomonas ovalis Chester (Kornberg, Gotto \& Lund, 1958; Kornberg \& Lund, 1959) and in Escherichia coli (Kornberg, Phizackerley \& Sadler, 1960; Vanderwinkel, Liard, Ramos \& Wiame, 1963). A similar effect was found with $P$. aeruginosa 8602 . Specific activities of isocitrate lyase in cell-free extracts from acetate-grown wild-type bacteria were approximately 30-fold greater than those from succinate-grown cultures (Table 3). Propionate-grown bacteria also produced isocitrate lyase, but the specific activity was only one quarter of that present in acetate-grown cultures.

Table 3. Isocitrate lyase activities of cell-free extracts of wild-type and acetate-negative mutants of Pseudomonas aeruginosa 8602

Assayed according to Dixon \& Kornberg (1959). Cultures were harvested after 16 hr growth and broken by ultrasonic treatment. The supernatant fluid was used for isocitrate lyase determination.

\begin{tabular}{|c|c|c|}
\hline Strain & $\begin{array}{l}\text { Carbon source } \\
\text { for growth }\end{array}$ & $\begin{array}{c}\text { Specific } \\
\text { activity of } \\
\text { isocitrate } \\
\text { lyase* }\end{array}$ \\
\hline Wild-type & $\begin{array}{l}\text { Acetate } \\
\text { Propionate } \\
\text { Succinate }\end{array}$ & $\begin{array}{l}\mathrm{I} 4 \cdot 3 \\
3 \cdot 5 \\
0.45\end{array}$ \\
\hline At I & $\begin{array}{l}\text { Propionate } \\
\text { Succinate }\end{array}$ & $\begin{array}{l}0.01 \\
0.01\end{array}$ \\
\hline At 8 & $\begin{array}{l}\text { Propionate } \\
\text { Succinate }\end{array}$ & $\begin{array}{l}0.04 \\
0.02\end{array}$ \\
\hline $\left.\begin{array}{l}\text { At } 2 \\
\text { At } 3 \\
\text { At } 4 \\
\text { At } 5 \\
\text { At } 6 \\
\text { At } 7 \\
\text { At } 20\end{array}\right\}$ & Succinate & $\left\{\begin{array}{l}0.06 \\
0.06 \\
0.07 \\
0.04 \\
-\dagger \\
0.02 \\
-\dagger\end{array}\right.$ \\
\hline $\left.\begin{array}{ll}\text { At } 14 \\
\text { At } 22\end{array}\right\}$ & Succinate & $\begin{array}{l}0.06 \\
0.10\end{array}$ \\
\hline $\left.\begin{array}{ll}\text { At } & 9 \\
\text { At } & 11 \\
\text { At } & 13 \\
\text { At } & \text { I } 5 \\
\text { At } & \text { I6 } \\
\text { At } & 21\end{array}\right\}$ & Succinate & $\left\{\begin{array}{l}0.38 \\
0.57 \\
0.44 \\
0.60 \\
0.58 \\
0.46\end{array}\right.$ \\
\hline
\end{tabular}

* $\mu$ moles isocitrate utilized per mg. soluble protein per hr.

$\dagger$ Not determined quantitatively, but isocitrate lyase activity minimal in preliminary assays.

Enzyme assays of cell-free extracts from succinate-grown cultures of the II mutants which grew on acetate + glyoxylate showed that 9 strains (At I to At 8, At 20) were 
deficient in isocitrate lyase (Table 3 ). It could be argued that the assays were performed on extracts of severely repressed (succinate-grown) cultures which would be expected to have low enzyme activity. For this reason, two mutants (At I, At 8) were grown in propionate medium and extracts assayed for isocitrate lyase activity. Under these partially derepressed conditions there was no significant increase in the specific activity. It was concluded that the 9 mutants were true isocitrate lyase-negative strains and since they all grew on propionate it appears that this glyoxylate cycle enzyme is not essential for propionate utilization by Pseudomonas aeruginosa.

Mutant At 15 also grew on acetate + glyoxylate and propionate but its isocitrate lyase activity did not differ significantly from that of the wild type. Mutant At 14 was the only mutant which grew on acetate + glyoxylate but not on propionate. It had only one third of the isocitrate lyase activity of the wild type strain under the same conditions (Table 3). However, as growth on propionate is not dependent on isocitrate lyase, the low activity of the enzyme in this strain was considered to be secondary to some other genetic defect.

Six of the 9 strains unable to grow on acetate + glyoxylate were also assayed for isocitrate lyase activity. In 5 of these strains (At 9, At II, At 13, At 16, At 21) the enzyme activity was not significantly different from that of the wild-type strain. Mutant At 22, which was also unable to grow on propionate, had only a quarter of the isocitrate lyase activity of the wild-type strain. It was thought that like mutant At 14 a defective isocitrate lyase was not the primary genetic defect.

Table 4. Malate synthase activities of cell-free extracts of wild-type and acetate-negative mutants of Pseudomonas aeruginosa 8602

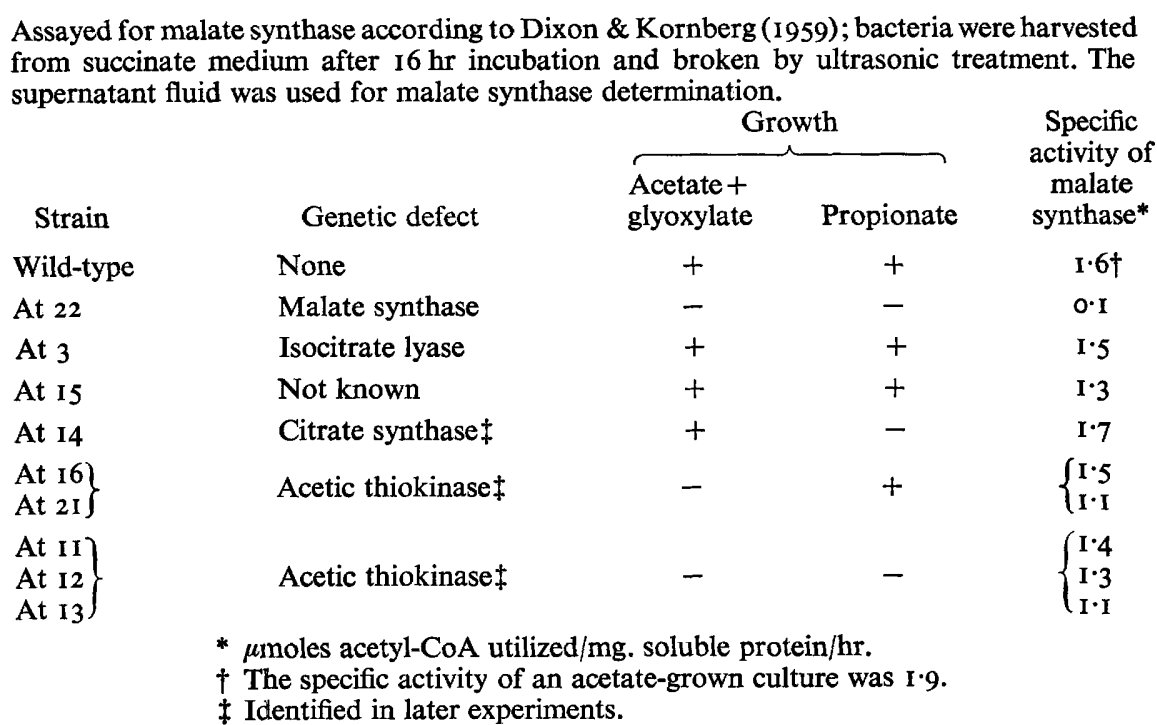

Malate synthase

The specific activity of malate synthase in cell-free extracts from the wild-type strain was similar for acetate-grown and succinate-grown cultures (Table 4). Mutant At 22, which was unable to grow on acetate + glyoxylate or on propionate, produced less than I0 \% of the malate synthase activity of the wild-type strain and it was concluded that 
it was a malate synthase-deficient mutant. The low activity of isocitrate lyase in this mutant was thought to be a secondary effect due to metabolic repression. It is unlikely that a regulator mutation had resulted in co-ordinate repression of these two enzymes, since the activities of malate synthase, but not of isocitrate lyase, are similar in wild-type cultures grown on either acetate or succinate. Mutant At I4, which also had a low isocitrate lyase activity, had a normal malate synthase activity. Six other mutants, all of which were unable to grow on acetate + glyoxylate, also had normal malate synthase activities.

\section{Citrate synthase}

Citrate synthase activity was also similar in cell-free extracts from the wild-type strain grown on acetate or succinate (Table 5). The only mutant with a very low citrate synthase activity was At 14 which also produced less than the normal amount of

Table 5. Citrate synthase activities of cell-free extracts of wild-type and acetate-negative mutants of Pseudomonas aeruginosa 8602

Citrate synthase was assayed according to Dixon \& Kornberg (1959). Bacteria were harvested after incubation for $16 \mathrm{hr}$ in succinate medium and broken by ultrasonic treatment. The supernatant fluid was used for citrate synthase determination.

\begin{tabular}{|c|c|c|c|c|}
\hline \multirow[b]{2}{*}{ Strain } & \multirow[b]{2}{*}{ Genetic defect } & \multicolumn{2}{|c|}{ Growth } & \multirow{2}{*}{$\begin{array}{l}\text { Specific } \\
\text { activity of } \\
\text { citrate } \\
\text { synthase* }\end{array}$} \\
\hline & & $\begin{array}{l}\text { Acetate }+ \\
\text { glyoxylate }\end{array}$ & Propionate & \\
\hline Wild-type & None & + & + & $2 \cdot 8 \dagger$ \\
\hline At 14 & Citrate synthase & + & - & 0.2 \\
\hline At 22 & Malate synthase & - & - & $2 \cdot 3$ \\
\hline $\left.\begin{array}{l}\text { At } 6 \\
\text { At } 8\end{array}\right\}$ & Isocitrate lyase & + & + & $\left\{\begin{array}{l}3 \cdot 0 \\
2 \cdot 0\end{array}\right.$ \\
\hline At 15 & Not known & + & + & $I \cdot 6$ \\
\hline $\left.\begin{array}{ll}\text { At } & 9 \\
\text { At } & 16 \\
\text { At } 21\end{array}\right\}$ & Acetic thiokinase & - & + & $\left\{\begin{array}{l}2 \cdot 4 \\
I \cdot 6 \\
2 \cdot 2\end{array}\right.$ \\
\hline $\left.\begin{array}{ll}\text { At } & \text { IO } \\
\text { At } & \text { I I } \\
\text { At } & \text { I } 2 \\
\text { At } & \text { 1 } 3\end{array}\right\}$ & Acetic thiokinase & - & - & $\left\{\begin{array}{l}I \cdot 8 \\
I \cdot 7 \\
2 \cdot 0 \\
I \cdot I\end{array}\right.$ \\
\hline
\end{tabular}

isocitrate lyase on succinate medium (Table 2). A low citrate synthase activity could result in an increased intracellular concentration of oxaloacetate and consequently of phosphoenolpyruvate which is thought to be the specific co-repressor of isocitrate lyase synthesis in Escherichia coli (Kornberg, 1966). It is concluded that the acetatenegative character of mutant At 14 is due partly to a genetic deficiency of citrate synthase and partly to the consequent phenotypic deficiency of isocitrate lyase. The amount of citrate synthase produced by the mutant ( $7 \%$ of that of the wild type) is sufficient for growth on succinate but not on propionate.

The malate synthase mutant At 22 produced normal citrate synthase activity as did the two isocitrate lyase mutants tested (At 6, At 8). Cell-free extracts of mutants At I5 
and 7 of the mutants unable to grow on acetate + glyoxylate also had high citrate synthase activities although in some cases these were less than that of the wild-type strain (Table 5).

\section{Acetic thiokinase}

The wild-type strain grown on succinate had only $30 \%$ of the acetic thiokinase activity of acetate-grown cultures (Table 6). Eight of the remaining unclassified mutants had significantly lower acetic thiokinase activities than the wild type in succinate medium. It was concluded that this defect could explain their inability to

Table 6. Acetic thiokinase activities of cell-free extracts of wild-type and acetatenegative mutants of Pseudomonas aeruginosa 8602

Acetic thiokinase was assayed according to Jones \& Lipmann (1955). Cultures were harvested from succinate medium after $16 \mathrm{hr}$ growth and broken by ultrasonic treatment. The supernatant fluid was used for acetic thiokinase determination.

$\begin{array}{lcc}\text { Strain } & \begin{array}{c}\text { Growth on } \\ \text { propionate }\end{array} & \begin{array}{c}\text { Specific } \\ \text { activity of } \\ \text { acetic } \\ \text { thiokinase* }\end{array} \\ \text { Wild-type } & + & \text { I.3† } \\ \text { At I2 } & - & 0.12 \\ \text { At I3 } & - & 0.40 \\ \text { At I0 } & - & <0.04 \\ \text { At I I } & - & <0.04 \\ \text { At I9 } & - & <0.04 \\ \text { At 9 } & + & 0.04 \\ \text { At I6 } & + & <0.04 \\ \text { At 2 I } & + & <0.04\end{array}$

+ , Growth (about $10^{\circ}$ bacteria/ml.) after $24-36 \mathrm{hr}$ incubation at $37^{\circ}$; - , no visible growth after $36 \mathrm{hr}$ incubation at $37^{\circ}$.

* $\mu$ moles acetyl-CoA formed/mg. soluble protein $/$ hr.

$\dagger$ The specific activity of an acetate-grown culture was $4 \cdot 5$.

grow on acetate. A few acetate-negative mutants of all types grew slightly in liquid acetate medium after $36 \mathrm{hr}$ incubation (Table 2) and mutant At 12 regularly did so. This could be due to the residual acetate activating activity (10\% of wild type) although mutant At 13 which had a third of the wild-type activity seldom produced more than a trace of growth after $48 \mathrm{hr}$. Three of these mutants grew on propionate whereas the other 5 were unable to do so. The implications of this finding are discussed later.

Mutant At 15 was not tested for acetic thiokinase since it grew normally on acetate + glyoxylate and was presumed to activate acetate. It produced normal amounts of isocitrate lyase, malate synthase and citrate synthase and no enzyme defect has been detected.

\section{Transduction analysis}

The pseudomonad phage Fir6 can be used to transduce genetic markers in Pseudomonas aeruginosa 8602 . Phage lysates from the wild-type strain can be used to produce amidase-positive transductants from amidase-negative mutants (Skinner \& Clarke, 1965; Brammar et al. 1967). No transductants were obtained when the amidase-negative mutants Am 4 or Am 5 were infected with a phage lysate propagated on mutant Am 9. This suggested that these mutations were closely linked. A detailed 
analysis by the use of regulator mutants has shown that the amidase structural and regulator genes occur together on a small segment of the bacterial chromosome (Brammar et al. 1967).

When a lysate from mutant Am 9 was mixed with mutants lacking either isocitrate lyase At 3, or acetic thiokinase At Io, equal numbers of transductants were obtained on both acetate and acetamide plates. This suggested that the amidase gene is not closely linked to the isocitrate lyase or acetic thiokinase genes since co-transduction resulting from close linkage would have resulted in a decrease in the number of transductants on acetamide plates. This was confirmed by selecting $\mathrm{At}^{+}$transductants from an $\mathrm{Am}^{-} \times \mathrm{At}^{-}$cross and replicating to acetamide plates. Using three different $\mathrm{At}^{-}$ strains as recipients, no $\mathrm{At}^{+} \mathrm{Am}^{-}$colonies were found among the $\mathrm{At}^{+}$transductants tested (Table 7).

\section{Table 7. Pseudomonas aeruginosa 8602: non-linkage of $\mathrm{At}^{-}$ mutations to a mutation in the amidase structural gene}

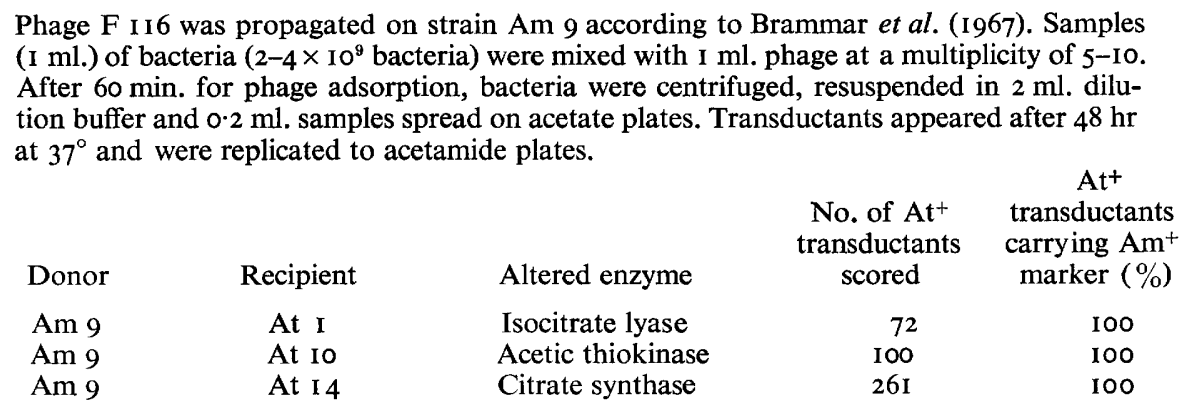

\section{DISCUSSION}

It has been shown that an active amidase and an operative glyoxylate cycle are necessary for growth of Pseudomonas aeruginosa 8602 with acetamide as carbon source. A mutation leading to a deficiency in one of five enzymes results in an acetamidenegative phenotype. The metabolic pathway for acetamide and the location of the enzyme mutations identified in this study are given in Fig. I. The Io mutants able to grow on acetate but not on acetamide lacked amidase activity. Strains deficient in an amide permease would also be unable to grow on acetamide. Amide permease activity in this organism appears to be a constitutive character and no permease-negative mutants were isolated. The amidase-negative mutant Am Io has been shown to take up $\mathrm{I}-\left[{ }^{14} \mathrm{C}\right]$ acetamide at the same rate as the wild-type strain (Brammar, McFarlane \& Clarke, I966). Of the 20 acetate-negative mutants studied, 9 were considered to have defects in isocitrate lyase, one in malate synthase, one in citrate synthase and 8 in acetic thiokinase. It is not possible to say whether these were all mutations in structural genes or whether some may have been mutations in regulator genes. No enzyme defects were found for mutant At 15 .

Mutants which lack isocitrate lyase have also been described for Escherichia coli (Ashworth \& Kornberg, 1964; Kornberg \& Smith, 1966). They are unable to grow with acetate but can grow with propionate, indicating that isocitrate lyase is not required for growth with propionate. We have shown that a similar situation exists in 
Pseudomonas aeruginosa. The increased synthesis of isocitrate lyase on propionamide and propionate medium is therefore gratuitous. These results were confirmed and extended by Chapman \& Duggleby (1967) with our strain of P. aeruginosa; they found that the isocitrate lyase-negative mutants At I and At 8 did not grow on the evennumbered monocarboxylic acids $\left(\mathrm{C}_{2}-\mathrm{C}_{10}\right)$ which are degraded to acetyl-CoA by $\beta$-oxidation. Both strains grew on the odd-numbered mono-carboxylic acids $\left(\mathrm{C}_{3}-\mathrm{C}_{9}\right)$ which produce propionyl-CoA as the terminal product of $\beta$-oxidation. Both mutants also grew on the even-numbered dicarboxylic acids $\left(\mathrm{C}_{3}-\mathrm{C}_{9}\right)$ but not on the oddnumbered dicarboxylic acids $\left(\mathrm{C}_{3}-\mathrm{C}_{9}\right)$ which are thought to produce acetyl-CoA by the decarboxylation of malonyl-CoA.

The metabolic pathway for propionate utilization by pseudomonads has not been studied in detail. Some experiments suggest that it may be converted to pyruvate via lactate (Vagelos, Earl \& Stadtman, 1959; Sokatch, 1967). A preliminary report states that the enzymes of this pathway are present in Escherichia coli (Wegener, Reeves \& Aj1, 1967). Ochromas malhamensis carboxylates propionate to form succinyl-CoA (Arnstein \& White, 1962) and Prototheca zopfii converts propionate to acetyl-CoA via the malonic semialdehyde pathway (Callely \& Lloyd, 1964; Lloyd \& Callely, I965). It is improbable that the last pathway is operative in Pseudomonas aeruginosa 8602 since it would require a functioning glyoxylate cycle and the presence of isocitrate lyase. If propionate were to be converted to succinyl-CoA via methylmalonyl-CoA, growth on succinate and propionate would be essentially similar. However, this is not the case, since mutant At I4 which has a low citrate synthase activity grows with succinate but not with propionate. The lactate-pyruvate pathway may therefore be the operative one for propionate utilization in $P$. aeruginosa.

The citrate synthase-deficient Pseudomonas mutant At 14 resembles Escherichia coli strain M 22-64 (Gilvarg \& Davis, 1956). However, M 22-64, unlike At I4, is unable to grow on succinate unless this is supplemented with $\alpha$-oxoglutarate. The residual activity of citrate synthase in mutant At $\mathrm{I} 4(7 \%)$ may be sufficient to allow $\alpha$-oxoglutarate and related compounds to be synthesized at an adequate rate for growth. An alternative explanation is that other pathways operate for this purpose in pseudomonads. The lowered isocitrate lyase activity of this mutant is almost certainly due to an increase in the intracellular concentration of the metabolic repressor of the enzyme. This provides an interesting example of a secondary metabolic effect on the activity of an enzyme of a genetic lesion in a different enzyme. The variable citrate synthase activities of the acetic thiokinase mutants (Table 5) may reflect variation of intracellular concentrations of metabolic intermediates affecting the regulation of citrate synthase.

Eight Pseudomonas mutants were classified as defective in acetic thiokinase. This enzyme assay measures acetate activation in the presence of ATP and coenzyme A and the existence of other acetate activating enzymes in Pseudomonas aeruginosa 8602 cannot be ruled out. Kornberg \& Madsen (1958) found acetic thiokinase in $P$. fluorescens but Escherichia coli is known to activate acetate by means of acetate kinase (EC 2.7.2.I) (Rose, Grunberg-Manago, Korey \& Ochoa, 1954) and phosphotransacetylase (EC 2.3.I.8) (Gilvarg \& Davis, 1956). The latter enzyme was reported in $P$. aeruginosa grown on valine (Sokatch, 1967).

Propionate and acetate are thought to be activated by the same thiokinase in Rhodospirillum rubrum (Eisenberg, 1955) and Prototheca zopfii (Callely \& Lloyd, 1964). 
Three of the 8 acetic thiokinase-deficient mutants of Pseudomonas aeruginosa 8602 were able to grow normally with propionate. A possible explanation for this finding is that the enzyme has been altered in such a way that it has retained sufficient activity to activate propionate but not acetate. Alternatively, acetate and propionate may be activated by different enzymes. This would seem unlikely since some of the acetateactivating enzyme mutants are also unable to grow on propionate.

It was not possible to locate any of these acetate genes on the bacterial chromosome. Transduction analysis is restricted to a small portion of the chromosome and could only reveal that the amidase gene did not appear to be linked to the isocitrate lyase, the acetic thiokinase or the citrate synthase genes.

We are grateful to the Science Research Council for a training grant to one of us (A.J.S.) and for a grant for the purchase of a Unicam SP 800 recording spectrophotometer (Unicam Ltd.)

\section{REFERENCES}

ARnstein, H. R. V. \& WhITE, A. M. (1962). The function of vitamin $B_{12}$ in the metabolism of propionate by the protozoan Ochromonas malhemensis. Biochem. J. 83, 264.

Ashworth, J. M. \& KorNBerg, H. L. (I964). The role of isocitrate lyase in Escherichia coli. Biochim. biophys. Acta 89, 383.

Brammar, W. J. \& ClaRke, P. H. (1964). Induction and repression of Pseudomonas aeruginosa amidase. J. gen. Microbiol. 37, 307.

Brammar, W. J., Clarke, P. H. \& Skinner, A. J. (1967). Biochemical and genetic studies with regulator mutants of the Pseudomonas aeruginosa 8602 amidase system. J. gen. Microbiol. $47,87$.

Brammar, W. J., McFarlane, N. D. \& Clarke, P. H. (1966). The uptake of aliphatic amides by Pseudomonas aeruginosa. J. gen. Microbiol. 44, 303.

CAllely, A. G. \& LloYd, D. (1964). The metabolism of propionate in the colourless alga, Prototheca zopfii. Biochem. J. 92, 338.

Chapman, P. J. \& Duggleby, R. G. (1967). Dicarboxylic acid catabolism by bacteria. Biochem. J. I03, $7 \mathrm{C}$.

DAvis, B. D. (1949). Isolation of biochemically deficient mutants of bacteria by limited enrichment of the medium. Archs. Biochem. 20, I66.

Dixon, G. H. \& Kornberg, H. L. (1959). Assay methods for key enzymes of the glyoxylate cycle. Biochem. J. 72, 3 P.

EISENBERG, M. A. (1955). The acetate-activating enzyme of Rhodospirillum rubrum. Biochim. biophys. Acta 16, 58.

Gilvarg, C. \& Davis, B. D. (1956). The role of the tricarboxylic acid cycle in acetate oxidation in Escherichia coli. J. biol. Chem. 222, 307.

Holloway, B. W., Egan, J. B. \& Monk, M. (1960). Lysogeny in Pseudomonas aeruginosa. Aust. $J$. exp. Biol. 38, 32.

Jones, M. E. \& LipMann, F. (1955). Aceto-CoA-kinase. Meth. Enzymol. r, 585.

Kelly, M. \& Clarke, P. H. (1962). An inducible amidase produced by a strain of Pseudomonas aeruginosa. J. gen. Microbiol. 27, 305.

Kornberg, H. L. (I966). The role and control of the glyoxylate cycle in Escherichia coli. Biochem.J. 99, I.

KornberG, H. L. \& Krebs, H. A. (I957). Synthesis of cell constituents from $\mathbf{C}_{2}$-units by a modified tricarboxylic acid cycle. Nature, Lond. $\mathbf{x 7 9}, 988$.

KorNBERG, H. L. \& LUND, P. (1959). Influence of growth substrates on levels of glyoxylate cycle enzymes in Pseudomonas ovalis Chester. Biochem. J. 72, $33 \mathrm{P}$.

KornberG, H. L. \& MADSEN, N. B. (1958). The metabolism of $\mathrm{C}_{2}$ compounds in micro-organisms. 3 . Synthesis of malate from acetate via the glyoxylate cycle. Biochem. J. 68, 549.

Kornberg, H. L. \& SMITH, J. (I966). Temperature-sensitive synthesis of isocitrate lyase in Escherichia coli. Biochim. biophys. Acta 123, 654 . 
Kornberg, H. L., Gotto, A. M. \& Lund, P. (1958). Effect of growth substrates on isocitratase formation by $P_{\text {seudomonas ovalis Chester. Nature, Lond. 182, } 1430 .}$

Korngerg, H. L., Phizackerley, P. J. R. \& SadleR, J. R. (1960). The metabolism of $C_{2}$ compounds in micro-organisms. 5. Biosynthesis of cell materials from acetate in Escherichia coli. Biochem. J. 77,438 .

LEDERBERG, J. \& LEDERBERG, E. M. (1952). Replica plating and indirect selection of bacterial mutants. J. Bact. 63, 399.

Lloyd, D. \& CAllely, A. G. (1965). The assimilation of acetate and propionate by Prototheca zopfii. Biochem. J. $97,176$.

Lowry, O. H., Rosebrough, N. J., Farr, A. L. \& Randall, R. J. (195I). Protein measurement with the Folin phenol reagent. J. biol. Chem. x93, 265.

Rose, I. A., Grunberg-Manago, M., Korey, S. R. \& OchOA, S. (1954). Enzymatic phosphorylation of acetate. J. biol. Chem. $211,737$.

SkinNer, A. J. \& Clarke, P. H. (I965). $\mathrm{C}_{2}$ mutants of Pseudomonas aeruginosa. J. gen. Microbiol. 39, viii.

SокатсH, J. R. (1967). Metabolism of propionate by enzymes of Pseudomonas aeruginosa grown on valine. Bact. proc. 67, 133 .

Stadtman, E. R. (1957). Preparation and assay of acyl coenzyme A and other thiol esters: use of hydroxylamine. Meth. Enzymol.3, 931.

Vagelos, P. R., Earl, J. M. \& Stadtman, E. R. (1959). Propionic acid metabolism. II. Enzymatic synthesis of lactyl pantetheine. J. biol. Chem. 234, 765 .

VANDERWinkel, E., Liard, P., RAMOs, F. \& Wiame, J. M. (1963). Genetic control of the regulation of isocitritase and malate synthase in Escherichia coli $\mathrm{K}$ I2. Biochem. biophys. res. Commun. 12 , I57.

Wegener, W. S., Reeves, H. C. \& Ajl, S. J. (1967). Propionate metabolism in Escherichia coli. Bact. Proc. 67, 133. 